\title{
Growth, production and productivity of the Arctic sympagic amphipod Gammarus wilkitzkii
}

\author{
M. Poltermann* \\ Alfred Wegener Institute for Polar and Marine Research, Columbusstrasse, 27515 Bremerhaven, Germany
}

\begin{abstract}
The amphipod Gammarus wilkitzkii Birula is one of the major macrofauna species permanently inhabiting the subsurface of Arctic sea ice. It reaches an age of 5 yr with a measured maximum body length of $62.3 \mathrm{~mm}$. The growth of this species is best described by the Gompertz growth function, which gives asymptotic final lengths of 69.2 and $64.6 \mathrm{~mm}$ respectively for males and females. Individuals of 46 to $52 \mathrm{~mm}$ length show the highest individual production, whereas the length class 31 to $36 \mathrm{~mm}$ is the most productive within the investigated population. The somatic $P / B$ ratio (productivity) of the investigated $G$. wilkitzkii population $\left(0.398 \mathrm{yr}^{-1}\right)$ is low compared to other amphipod species from boreal and polar regions. This is discussed with respect to the permanent low water temperature, the low energy content of the food, and the high mortality of juveniles under Arctic sea ice. The overall growth performance, $\Psi$, of $G$. wilkitzkii is not significantly different from other Gammarus species living under boreal conditions. It is therefore assumed that the growth is predominantly determined genetically rather than by environmental conditions
\end{abstract}

KEY WORDS: Sea ice - Sympagic amphipod Gammarus wilkitzki - Growth - Overall growth performance $\cdot P_{\mathrm{s}} / B$ ratio Arctic

\section{INTRODUCTION}

Arctic sea ice represents a very dynamic environment which is, among other things, characterised by permanently low temperatures, highly variable salinities and limited and only seasonally available food sources (Carey 1985, Melnikov 1997). Evolutionarily, only a few macrofauna species ( $>5 \mathrm{~mm}$ ) have adapted to life in these unstable and extreme conditions. In terms of biomass Gammarus wilkitzkii Birula is the dominant amphipod species permanently inhabiting the underside of Arctic sea ice (Gulliksen \& Lønne 1989, Lønne \& Gulliksen 1991a,b,c, Melnikov 1997, Poltermann 1998). The biomass can reach $10.12 \mathrm{~g} \mathrm{~m}^{-2}$ with densities of up to 368 ind $\mathrm{m}^{-2}$ (Poltermann 1997). Feeding on ice-produced material and in turn preyed upon by pelagic predators (polar cod) G. wilkitzkii represents a key species in the ice-based Arctic food web (Poltermann 1997, 1998, Werner 1997). Earlier studies

\footnotetext{
- Present address: Norwegian Polar Institute, 9296 Tromsø
} Norway. E-mail: michael.poltermann@npolar.no showed that G. wilkitzkii is physiologically well adapted to the high osmotic stress and the very low temperatures under the Arctic sea ice (Aarset \& Aunaas 1987, 1990, Aarset 1991). No information, however, is available yet concerning possible adaptations in growth. The present investigation is focused on the analysis of growth and productivity of G. wilkitzkii, and a comparison with other amphipod species living under similar or different environmental conditions.

\section{MATERIAL AND METHODS}

Sampling of the sympagic amphipod Gammarus wilkitzkii (Fig. 1) was carried out in summer 1994 north-west of Franz Josef Land $\left(82^{\circ} 09^{\prime} \mathrm{N}, 42^{\circ} 02^{\prime} \mathrm{E}\right.$; $\left.82^{\circ} 23^{\prime} \mathrm{N}, 40^{\circ} 54^{\prime} \mathrm{E} ; 81^{\circ} 51^{\prime} \mathrm{N}, 41^{\circ} 17^{\prime} \mathrm{E}\right)$ and in the southern part of the archipelago $\left(80^{\circ} 20^{\prime} \mathrm{N}, 52^{\circ} 41^{\prime} \mathrm{E}\right)$ (Fig. 2). Ice thickness varied from 0.2 to $2.70 \mathrm{~m}$; ice cover was about 40 to $50 \%$, with a mixture of multiand first year ice. The ice underside was relatively smooth at all sampling sites; no large pressure ridges were present. Because of the origin of older sea ice, 


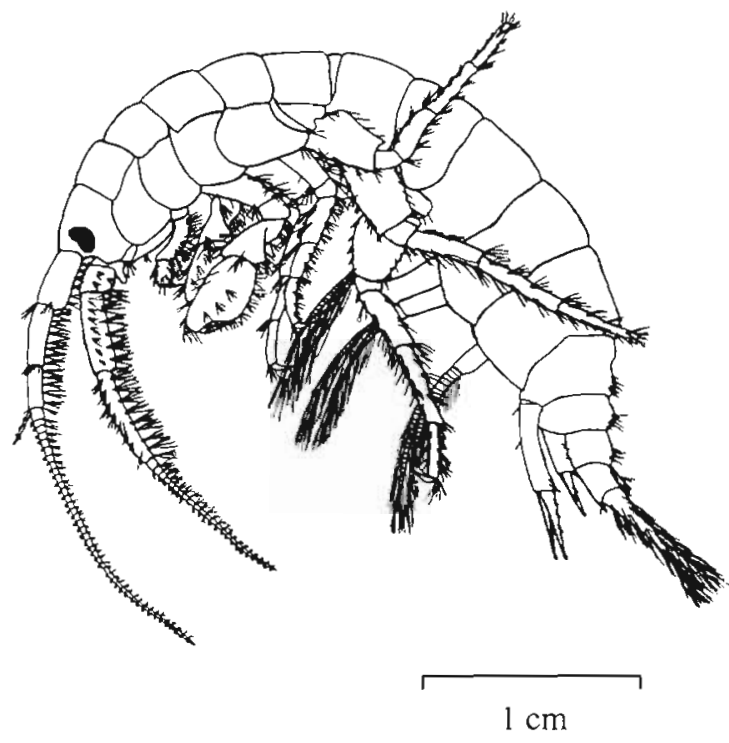

Fig. 1. The Arctic sympagic amphipod Gammarus wilkitzkii Birula 1897

which generally drifts through the Franz Josef Land area from the Arctic Basin (Abramov \& Zubakin 1993), the amphipods from both sampling areas are considered as 1 population. A diver-operated electric suction pump (Lønne 1988) in combination with a randomly placed standard frame $(25 \times 25 \mathrm{~cm})$ were used to remove all animals from the ice underside, brine channels and melting holes. The amphipods were immediately preserved in $4 \%$ buffered formaldehyde. Body length of the amphipods was measured along the dorsal line from the tip of the rostrum to the end of the telson using a video-based image analysing system (VIDS III, Mobrey Bestobell) with a measurement pre- cision of $0.001 \mathrm{~mm}$. For determination of the wet weight (WW) the amphipods were gently blotted and weighed to the nearest $0.001 \mathrm{~g}$. Ash-free dry weight (AFDW) was calculated using the conversion factor WW: $A F D W=6.47$, according to Rumohr et al. (1987). All individuals with oostegites were considered as female, those without oostegites as male, and those both without oostegites and smaller than the smallest female as juvenile. The age of $G$. wilkitzkii was estimated by length frequency distribution at $1 \mathrm{~mm}$ intervals according to Grant et al. (1987). Differences in the length-weight relation between males and females were tested by ANOVA ( $95 \%$ significance level).

For growth analysis 2 growth models were tested: von Bertalanffy growth model

$$
L_{t}=L_{\infty} \cdot\left\{1-\exp \left[-k \cdot\left(t-t_{0}\right)\right]\right\}
$$

Gompertz growth model

$$
L_{t}=L_{\infty} \cdot \exp \left\{-\exp \left[-k \cdot\left(t-t_{0}\right)\right]\right\}
$$

where $L_{t}=$ length, $L_{\infty}=$ asymptotic final length, $k=$ growth constant, $t_{0}=$ age at length 0 and $t=$ age.

Estimation of the growth parameters $k$ and $L_{\infty}$ was performed by a Ford-Walford-Plot (Ricker 1975):

von Bertalanffy growth model

$$
L_{t+1}=a+b \cdot L_{t} \rightarrow k=-\ln (b) ; L_{\infty}=a /(1-b)
$$

where $a$ and $b=$ constants

Gompertz growth model

$\ln \left(L_{t+1}\right)=a+b \cdot \ln \left(L_{t}\right) \rightarrow k=-\ln (b)_{;} L_{c o}=\exp [a /(1-b)]$

Annual somatic production $\left(P_{\mathrm{s}}\right)$ and productivity $\left(P_{\mathrm{s}} / B\right.$ ratio) of Gammarus wilkitzkii were calculated by applying the weight-specific growth rate (WSGR) method, which uses the length-weight relation
$0^{\circ} 00^{\prime} \mathrm{E}$

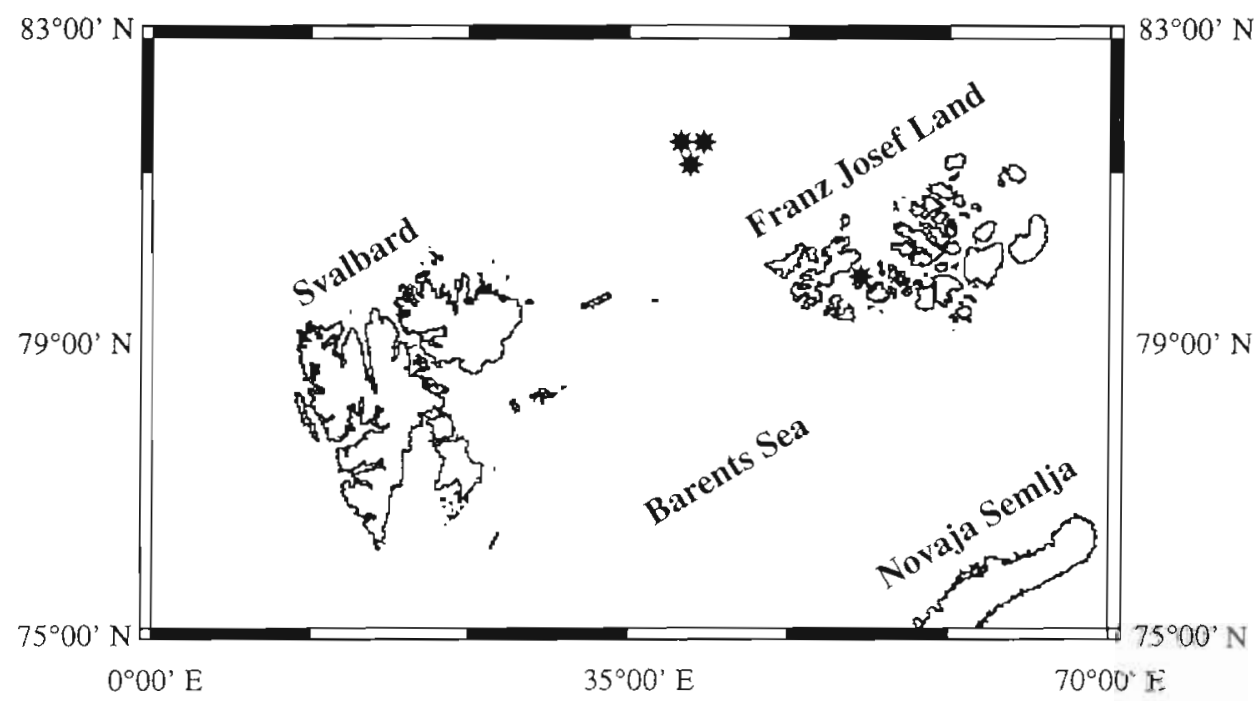

Fig. 2. Sampling area of Gammarus wilkitzkii carried out in summer 1994 on Franz Josef Land and north-west of the archipelago 
$\left(W=a \cdot L^{b}\right)$, length frequency distribution, and growth function (Crisp 1984):

von Bertalanffy growth model

$$
\mathrm{WSGR}_{1}=b \cdot k \cdot\left(L_{\infty}-L_{t}\right)
$$

Gompertz growth model

$$
\mathrm{WSGR}_{i}=b \cdot k \cdot \ln \left(L_{\infty} / L_{i}\right)
$$

where $i=$ length class (LC) $i$ and WSGR $_{1}=$ weightspecific growth rate per $\mathrm{LC}_{i}$.

$P_{\mathrm{s}}$ for each length class was calculated according to the equation:

$$
P_{s_{1}}=\mathrm{WSGR}_{1} \cdot W_{1} \cdot N_{i}
$$

where $W_{i}=$ mean individual weight at mean length of the $\mathrm{LC}_{i}$ and $N_{1}=$ number of individuals per $\mathrm{LC}_{1}$.

The sum of $P_{\mathrm{s}}$ of each length class $\left(P_{\mathrm{s}_{1}}\right)$ yields the total somatic production of the investigated population:

$$
P_{s}=\sum P_{s}
$$

The annual $P_{s} / B$ ratio was determined as follows:

$$
P_{\mathrm{s}} / B=\sum P_{\mathrm{s}_{1}} / \sum W_{j} \cdot N_{j}
$$

To avoid an overestimation of the somatic production of Gammarus wilkitzkii by the highly variable gonad weight of the females, only the length-weight relation of males was used for the calculation.
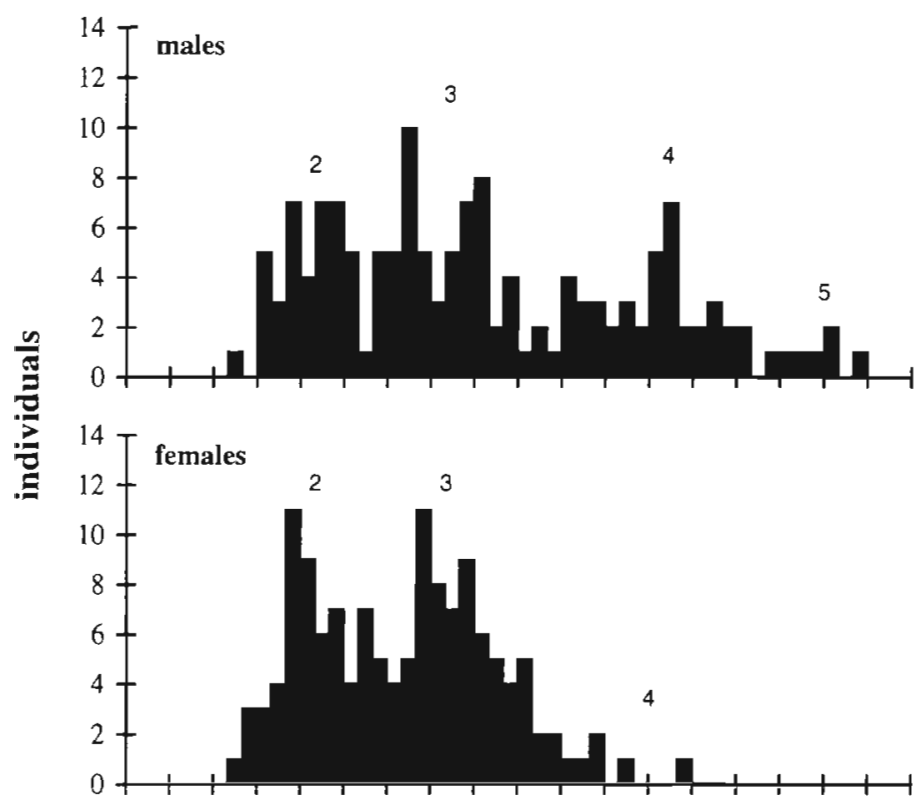

$\begin{array}{llllllllllllllllll}12 & 15 & 18 & 21 & 24 & 27 & 30 & 33 & 36 & 39 & 42 & 45 & 48 & 51 & 54 & 57 & 60 & 63\end{array}$

\section{body length $(\mathrm{mm})$}

Fig. 3. Length frequency distribution of Gammarus wilkitzkii (males: $\mathrm{n}=144$; females: $\mathrm{n}=134$ ). Age estimation (given in years above bars) is based on cohorts

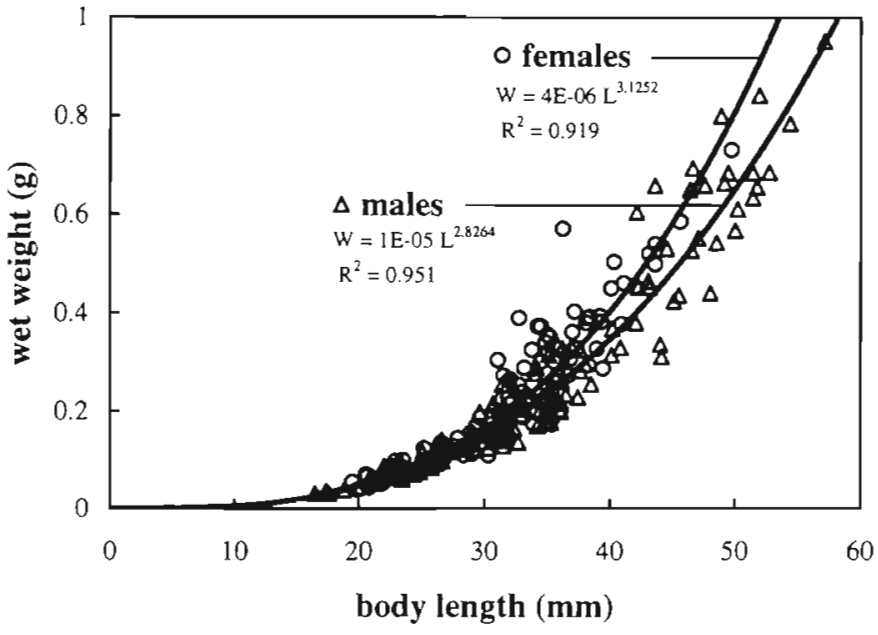

Fig. 4. Length-weight relation of Gammarus wilkitzkij (males: $\mathrm{n}=$ 129; females: $n=132$ )

The overall growth performance, $\Psi$, was calculated according to Brey (1999):

$$
\Psi=\log \left(M_{\max } / A_{\max }\right)
$$

where $M_{\text {max }}=$ maximum body weight $(\mathrm{kJ})$ and $A_{\max }=$ maximum age (yr).

\section{RESULTS}

\section{Length frequency distribution and age estimation}

The length frequency distribution of the investigated Gammarus wilkitzkii population allowed a distinction to be made between a maximum of 4 cohorts for males and 3 cohorts for females (Fig. 3). Considering the 2 identifiable cohorts of juveniles (see Fig. 6a) and only 1 reproduction cycle $\mathrm{yI}^{-1}$ (Steele \& Steele 1975) the maximum age of this species is estimated as 5 yr for males and $4 \mathrm{yr}$ for females. The smallest female was $19.5 \mathrm{~mm}$ long, the largest $49.7 \mathrm{~mm}$ and the largest male $62.3 \mathrm{~mm}$. The smallest free-living juveniles were $3.2 \mathrm{~mm}$ long.

\section{Growth, production and productivity}

The length-weight relation of Gammarus wilkitzkii was significantly different for males and females (ANOVA, $\mathrm{p}<0.05$ ) (Fig. 4). For the same body length, females showed a higher WW than males.

Growth of Gammarus wilkitzkii was described best by the Gompertz growth function, yielding $L_{\infty}$ of 69.2 and $64.6 \mathrm{~mm}$ for males and females, respectively. The Gompertz growth function estimates the maximum age 


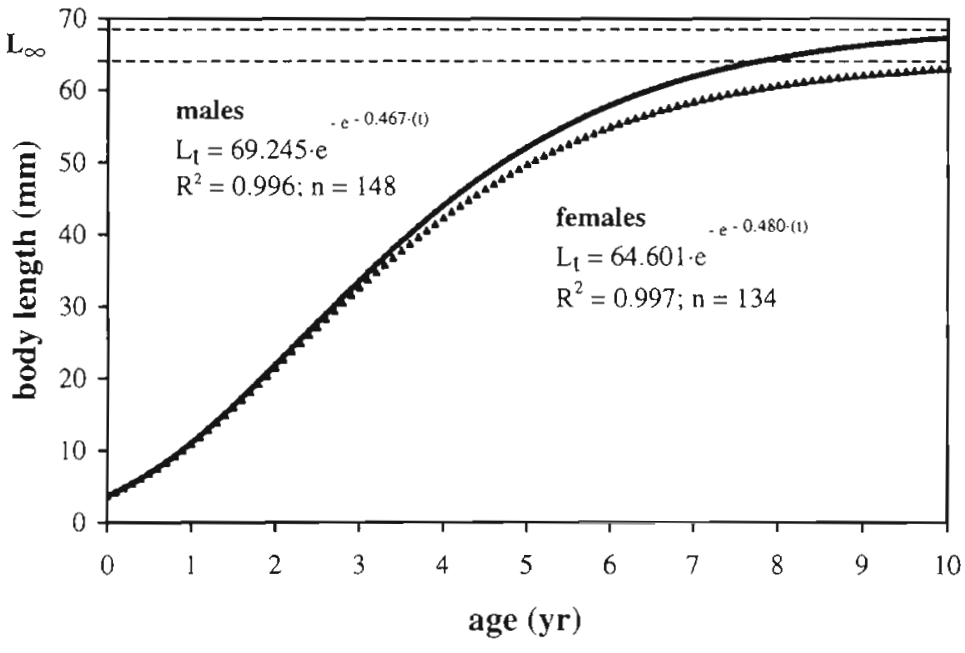

Fig. 5. Gompertz growth function for the Arctic sympagic amphipod Gammarus wilkitzkii ( $L_{\infty}=$ asymptotic final length)

attained by $G$. wilkitzkii to be about 9 to 10 yr (Fig. 5) Based on this model the ages of the largest male and female investigated were calculated to be 4.8 and $3.1 \mathrm{yr}$ respectively. The asymptotic lengths calculated by the von Bertalanffy growth function showed negative values $(-246.0$ and $-3728.6 \mathrm{~mm}$ for males and females, respectively) and therefore this model was unusable.

Fig. 6a shows the length frequency distribution of the investigated population of Gammarus wilkitzkii, with length classes 11 and $23 \mathrm{~mm}$ including the highest number of individuals. Amphipods with a body length of 46 to $52 \mathrm{~mm}$ showed the highest individual somatic production, with an increase of $0.019 \mathrm{~g} \mathrm{AFDW}$ $\mathrm{yr}^{-1}$ (Fig. 6b), whereas the length class 31 to $36 \mathrm{~mm}$ were most productive within the investigated population (Fig. $6 \mathrm{c}$ ). The calculated $P_{\mathrm{s}} / B$ ratio for $G$. wilkitzkil was $0.398 \mathrm{yr}^{-1}$ with a total somatic production of 3.601 $\mathrm{g}$ AFDW $\mathrm{yr}^{-1}$. In the Franz Josef Land area with a mean biomass of $10.12 \mathrm{~g} \mathrm{WW} \mathrm{m}^{-2}$ (Poltermann 1997), total somatic production sums up to $0.623 \mathrm{~g} \mathrm{AFDW} \mathrm{m}^{-2} \mathrm{yr}^{-1}$.

\section{DISCUSSION}

The maximum age of Gammarus wilkitzkii is estimated to be at least 5 yr. Thus G. wilkitzkii can be regarded as an amphipod species with a long lifetime (Gurjanova 1951).

Age estimations for the largest amphipods, derived from both the length frequency distribution and the Gompertz growth function, correspond well for males (both about 5 yi); for females, the observed variability in age estimation ( 4 and $3 y_{r}$, respectively) might be due to characteristics of the reproduction cycle. Females are carrying eggs and juveniles in brood pouches for at least half the year (Barnard 1959, Melnikov 1997), releasing the juveniles in April and May (Melnikov 1997 Poltermann 1997). They do not moult during this time and hence exhibit reduced growth Considering 2 to 3 possible reproduction cycles during a female's lifetime (Poltermann 1997), growth can be reduced for a total period of at least 1 to $1.5 \mathrm{yr}$. This explains the high individual variability in growth and age estimation of females.

Only 3 other amphipod species, the large Bovallia gigantea (Bone 1972) and Eusirus perdentatus (Klages 1993), both from Antarctica, and the deep-sea amphipod Eurythenes gryllus (Ingram \& Hessler 1987), are known to have lifespans similar to or exceeding that of Gammarus wilkitzkii. Living under comparable environmental conditions (low temperature, strong seasonality in food availability) they reach an age of 5, 8 and $9 \mathrm{yr}$, respectively. As reported by Arntz et al. (1994), species living in environments with permanently low temperatures show an increase in body size and lifespan compared to species in temperate waters. G. wilkitzkii can be regarded as a further example of this tendency. In comparison, the systematically closely related species $G$. oceanicus, which lives in temperate waters, reaches a body size of only $38 \mathrm{~mm}$ and has a lifespan of about 2.2 уг (Luppova 1991).

One ecological significance of a long lifespan can be to guarantee the reproductive success of a species (Sainte-Marie 1991). Once a year, Gammarus wilkitzkii produces a relatively high number of large eggs (149 to $187 ; \varnothing 0.7$ to $0.8 \mathrm{~mm}$; Steele \& Steele 1975 , Poltermann 1997). However, to accumulate sufficient energy for egg production from the food resources available under the sea ice during the short Arctic summer is presumably difficult. Hence, to secure the survival of the population, several reproduction cycles are necessary, which is guaranteed by the long lifespan of G. wilkitzkii.

Gammarus wilkitzkii exhibits a low growth rate, needing 5 yr to reach its maximum size. This is strongly supported by the fact that the oxygen consumption rates of this species are the lowest measured among Arctic and subarctic benthic amphipods (Werner et al. 1999). A low growth rate is also reported to be typical for organisms inhabiting polar regions (Arntz et al. 1994). Limited food availability and a low basic metabolism due to the permanently cold water temperatures are regarded as main factors responsible for the slow growth of polar organisms (Kanneworff 1965, Bone 1972, Bregazzi 1972, Rakusa-Suszczewski 1972, Percy 1975, Sagar 1980, Clarke 1988, Brey \& Clarke 1993). 

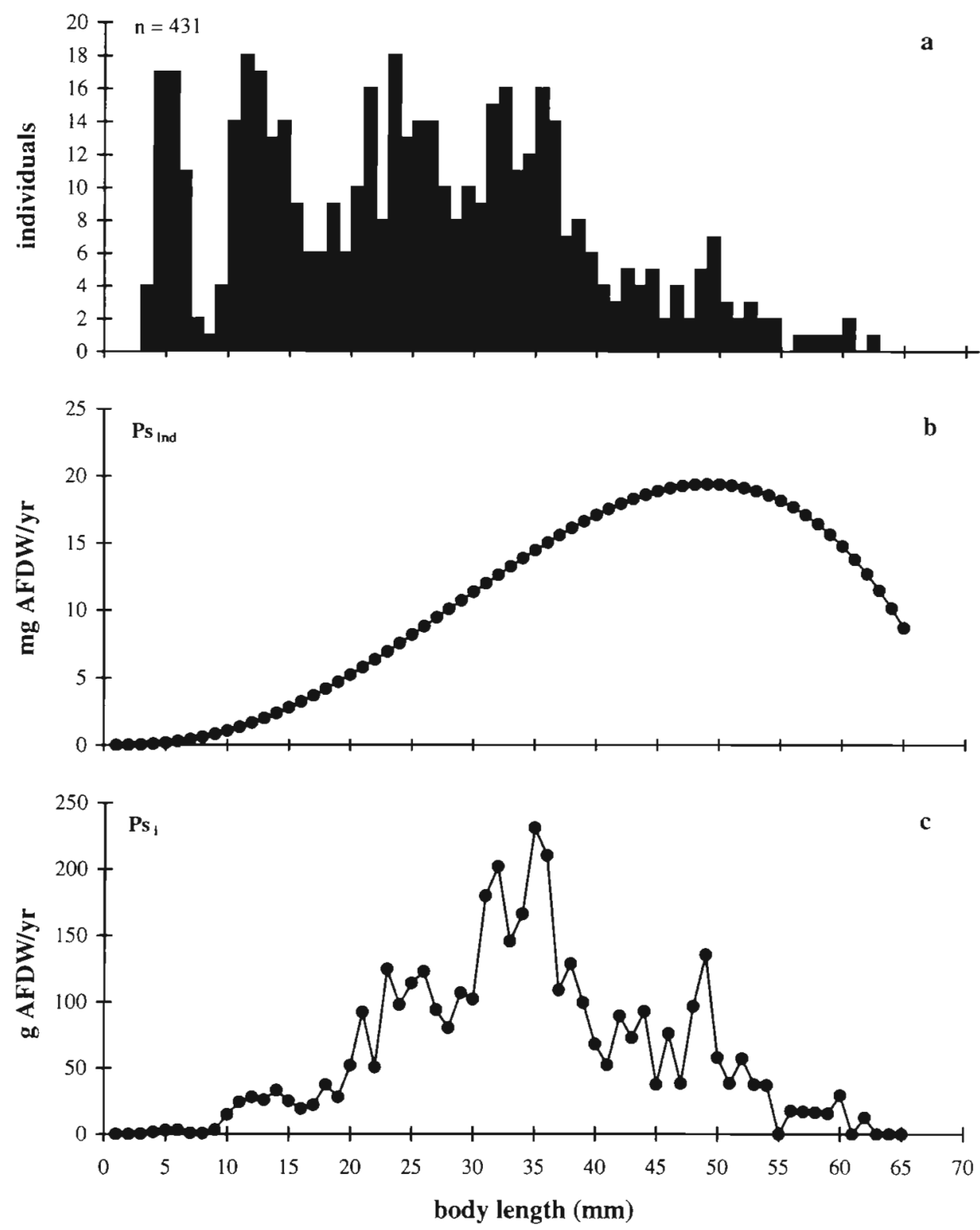

Fig. 6. (a) Length frequency distribution, (b) individual somatic production, $P_{s}$ ind., and (c) somatic production of the different length classes, $P_{51}$, of the investigated population of Gammarus wilkitzkii (AFDW: ash-free dry weight)

Inhabiting the Arctic sea ice, Gammarus wilkitzkii is exposed to an environment characterised by extreme physical and biological conditions, such as temperatures close to the freezing point, highly variable salinities and a seasonally limited food supply during the short Arctic summer (Carey 1985, Melnikov 1997). Obviously, G. wilkitzkii is evolutionarily adapted to live under such conditions. The question arises as to whether its low growth rate is one such adaptation. The individual growth of an organism is a non-linear process and can be described only by non-linear functions (Brey 1999). Therefore, for comparison among species, growth functions are not suitable. The species-specific overall growth performance, $\Psi$ (Brey 1999), is an index describing the time in which an organism reaches its maximum weight and is independent of a species-specific growth function. The comparison of $\Psi$ among salt and freshwater amphipods (Gammaridea) from boreal and polar regions shows that Gammarus species in general have a higher overall growth performance than other genera (Fig. 7). Within the genus Gammarus, however, $\Psi$ of $G$. wilkitzkii is not significantly different from boreal species (ANOVA, $p>0.05$ ). According to Brey (1999) $\Psi$ of sys- 


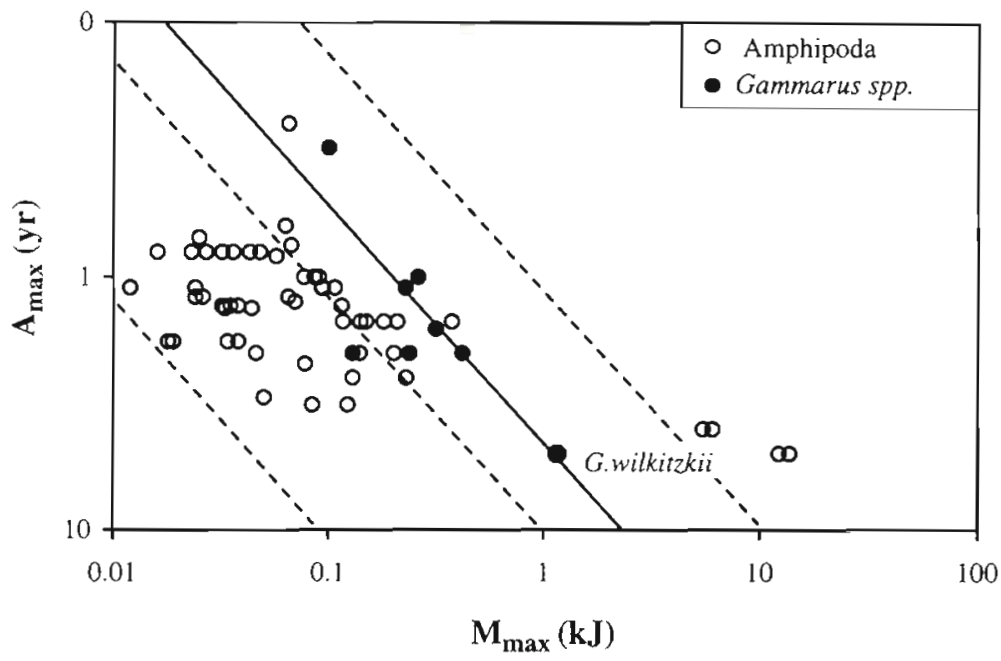

Fig. 7. Auximetric grid comparing overall growth performance, $\Psi$, of amphipod species from boreal and polar regions. Diagonal lines indicate equal values of $\Psi$. : species of the genus Gammarus-G. pulex, G. pseudolimnaeus, G. aequicauda, G. mucronatus (data collection: T. Brey) tions, these factors are discussed in detail for G. wilkitzkii.

\section{Temperature}

The metabolic rate of marine invertebrates is generally positively correlated to water temperature (Clarke 1991, Brey 1999). The low temperatures below Arctic sea ice $\left(-1.65\right.$ to $-1.7^{\circ} \mathrm{C}$, Melnikov 1997) could explain the low $P_{\mathrm{s}} / B$ ratio of Gammarus wilkitzkii in comparison to amphipod species from temperate latitudes, but not compared to the Antarctic species Bovallia gigantea (Fig. 8). The noticeable difference in productivity between these 2 polar species must be caused by factors others than temperature.

\section{Food}

tematically closely related species is primarily determined genetically rather than being dependent on the environmental conditions. This obviously also applies for amphipods of the genus Gammarus, and within those for G. wilkitzkii.

Somatic productivity of the sympagic amphipod Gammarus wilkitzkii is rather low compared to other amphipod species from polar and boreal habitats (Fig. 8). The $P_{s} / B$ ratio is mainly influenced by environmental factors such as temperature and food, but also by the proportion between small and large individuals within the population (Brey 1994). In the following sec-

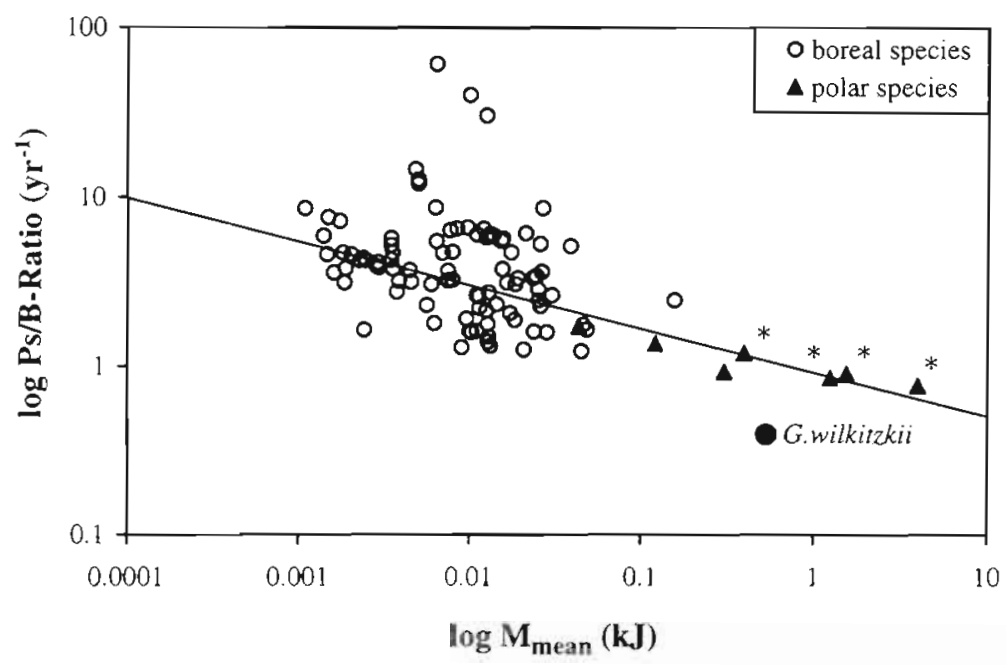

Fig. 8. Annual somatic $P_{s} / B$ ratio of Gammarus wilkitzkii in comparison to amphipod species from boreal and polar regions (data collection: $T$. Brey) ( $\%: P_{5} / B$ iatio of Bovallia gigantea; Thurston 1970, Bone 1972)
Food availability and food quality are important factors influencing individual growth and productivity of a population. A strong seasonal variability in food availability and food quality may result in a generally lower productivity of polar compared to boreal species. The higher $P_{\mathrm{s}} / B$ ratio of Bovallia gigantea in comparison to Gammarus wilkitzkii could be due to differences in their feeding strategies. B. gigantea is a typical predator and, as such, has a year-round supply of food of high energy content (Bone 1972, Iken 1995) G. wilkitzkii predominately feeds on detritus, animal remains, and ice algae (Poltermann 1997. Werner 1997). G. wilkitzkii is less dependent on the primary productivity cycle by feeding mainly on detritus, which is available year round, and hence food limitations may be less important than for many other polar organisms. Still, the energy content of this diet is low (Begon et al, 1989, Penzlin 1989) compared to the diet of $B$. gigantea and, furthermore, is subjected to seasonal oscillations in availability. This likely causes the lower $P_{\mathrm{s}} / B$ ratio of $G$. wilkitzkii compared to B. gigantea.

\section{Size distribution within the population}

A large proportion of small individuals, which are characterised by a high 
increase in body mass in a short time, results in a high $P_{\mathrm{s}} / B$ ratio of a population (Brey 1994). In the investigated population of Gammarus wilkitzkii only a comparatively small number of juveniles ( $<19 \mathrm{~mm}$ ) (Fig. 6a) have been found, only insignificantly increasing the $P_{5} / B$ ratio. The low number of juveniles may have the following causes: (1) Small amphipods were not sampled quantitatively, or live at other places. (2) G. wilkitzkii produces only a small number of juveniles annually. (3) The number of females within the population is low. (4) The mortality of juveniles is very high.

Samples were taken randomly with a non-selectively working suction pump. Therefore, small individuals were sampled in the same manner as large ones. No differences in the small-scale distribution between juveniles and adults could be observed at the sampling sites. The reported annual mean of 145 juveniles female $^{-1}$ (Poltermann 1997), which is considered to be very high for amphipods (Sainte-Marie 1991), and a male:female ratio of 1:0.9 (Poltermann 1997) indicate that reproduction-specific features are not likely to be responsible for the low productivity of the Gammarus wilkitzkii population. High mortality of juveniles after their release from the female brood pouch seems to be a more likely factor, influencing the $P_{\mathrm{s}} / B$ ratio negatively. Mortality of juveniles will probably increase considerably if they are released at sub-optimal food conditions and/or when there is high pressure from predators (e.g. polar cod, cannibalism). Also, juveniles are probably physiologically more sensitive to unstable environmental conditions (e.g. changes in salinity) than adults and might therefore be more strongly subjected to natural selection.

\section{Summary and conclusion}

Gammarus wilkitzkii exhibits a long lifespan with a low growth rate compared to most other, especially boreal, amphipod species. The discussion above showed that these findings are mainly related to the peculiarities of its polar environment-combined effects of extremely low water temperature and strongly seasonally variable food availability and food quality. However, the high frequency of occurrence and biomass under Arctic sea ice (Poltermann 1998) demonstrates its successful adaptation to this specific habitat. High mortality, especially of juveniles, which influences the productivity of the population negatively, is compensated by high fecundity and by several reproduction cycles during a long lifespan.

The species-specific overall growth performance, $\Psi$, of Gammarus wilkitzkii is determined genetically and is not significantly different to boreal Gammarus species. To ensure this overall growth performance, $G$. wilkitzki has to compensate for the limitations of permanently low water temperature and oscillation in food availability and quality. It has adapted successfully to these conditions by exhibiting a low growth rate but reaching a high age and a very large body size

Acknowledgements. I would like to thank the Alfred Wegener Institute, Bremerhaven, and the Murmansk Biological Institute for their financial and technical support. I am very grateful to V. G. Averintzev and S. Kühne for their assistance during diving operations. Special thanks to T. Brey for providing his data collection and the excellent help in statistical questions. Last but not least, thanks to $\mathrm{K}$. Iken for her constructive comments on the manuscript. This is AWI publication no. 1669 .

\section{LITERATURE CITED}

Aarset AV (1991) The ecophysiology of under-ice fauna. In: Sakshaug E. Hopkins CCE, Øritsland NA (eds) Proceedings of the Pro Mare Symposium on Polar Marine Ecology, Trondheim, 12-16 May 1990. Polar Res 10(1):309-324

Aarset AV, Aunaas T (1987) Physiological adaptations to low temperature and brine exposure in the circumpolar Amphipod Gammarus wilkitzkii. Polar Biol 8:29-133

Aarset AV, Aunaas T (1990) Effects of osmotic stress on oxygen consumption and ammonia excretion of the Arctic sympagic amphipod Gammarus wilkitzkii. Mar Ecol Prog Ser 58:217-224

Abramov VA, Zubakin GK (1993) Marine ice. In: Matishov GG, Galaktionov KV, Denisov VV, Drobysheva SS, Chinarina AD, Timofeeva SV (eds) Environment and ecosystems of the Franz-Josef-Land (archipelago and shelf). Russ Acad Sci Apatity, p 38-41

Arntz WE, Brey T, Gallardo VA (1994) Antarctic zoobenthos. Oceanogr Mar Biol Annu Rev 32:241-304

Barnard JL (1959) Epipelagic and under-ice Amphipoda of the Central Arctic Basin. Scientific studies at Fletcher's Ice Island T-3, 1952-1955. Geophys Res Pap 63:115-153

Begon M. Harper JL, Townsend CR (1989) Ecology. Individuals, populations and communities. Blackwell Scientific Publications, Oxford

Bone DG (1972) Aspects of the biology of the Antarctic amphipod Bovallia gigantea Pfeffer at Signy Island, South Orkney Islands. Br Antarct Surv Bull 27:105-122

Bregazzi PK (1972) Life cycles and seasonal movements of Cheirimedon femoratus (Pfeffer) and Tryphosella kergueIeni (Miers) (Crustacea: Amphipoda). Br Antarct Surv Bull $30: 1-34$

Brey T (1994) Empirische Untersuchungen zur Populationsdynamik makrobenthischer Evertebraten. Habil thesis, Universität Bremen

Brey I (1999) Growth performance and mortality in aquatic benthic invertebrates. Adv Mar Biol 35:153-223

Brey T, Clarke A (1993) Population dynamics of marine benthic invertebrates in Antarctic and subantarctic environments: are there unique adaptations? Antarct Sci 5(3): $253-266$

Carey AG (1985) Marine ice fauna: Arctic. In: Horner RA (ed) Sea ice biota. CRC Press, Inc, Boca Raton, FL, p 173-190

Clarke A (1988) Seasonality in the Antarctic marine environment. Comp Biochem Physiol 90B:461-473

Clarke A (1991) What is cold adaptation and how should we measure it? Am Zool 31:81-92 
Crisp DJ (1984) Energy flow measurements. In: Holme NA, McIntyre AD (eds) Methods for the study of marine benthos. Blackwell Scientific Publications, Oxford, p 284-372

Grant A, Morgan PJ, Olive PJW (1987) Use made in marine ecology of methods for estimating demographic parameters from size/frequency data. Mar Biol 95:201-208

Gulliksen B, Lonne OJ (1989) Distribution, abundance, and ecological importance of marine sympagic fauna in the Arctic. Rapp P-V Reun Cons Int Explor Mer 188:133-138

Gurjanova EF (1951) Beach hoppers of the seas of the USSR and adjacent waters (Amphipoda-Gammaridea). Acad Sci USSR, Moscow

Iken K (1995) Trophische Beziehungen zwischen Makroalgen und Herbivoren in der Potter Cove (King George-Insel, Antarktis). Dissertation, Universität Bremen

Ingram CL, Hessler RR (1987) Population biology of the deepsea amphipod Eurythenes gryllus: interferences from instar analyses. Deep-Sea Res 34(12):1889-1910

Kanneworff E (1965) Life cycle, food and growth of the amphipod Ampelisca macrocephala Liljeborg from the Oresund. Ophelia 2(2):305-318

Klages M (1993) Distribution, reproduction and population dynamics of the Antarctic gammaridean amphipod Eusirus perdentatus Chevreux, 1912 (Crustacea). Antarct Sci 5(4). $349-359$

Lonne OJ (1988) A diver-operated electric suction sampler for sympagic (under-ice) invertebrates. Polar Res 6:135-136

Lønne OJ, Gulliksen B (1991a) On the distribution of sympagic macro-fauna in the seasonally ice covered Barents Sea. Polar Biol 11:457-469

Lonne OJ, Gulliksen B (1991b) Source, density and composition of sympagic fauna in the Barents Sea. Polar Res 10(1) 289-294

Lonne OJ, Gulliksen B (1991c) Sympagic macro-fauna from multi year sea-ice near Svalbard. Polar Biol 11:471-477

Luppova EN (1991) Growth of Lagunogammarus oceanicus in nature and under experimental conditions. Biol Sea (Biol Mor) 5:50-56 (in Russian)

Melnikov I (1997) The Arctic sea ice system. Gordon and Beach Science Publishers, Amsterdam

Editorial responsibility: Otto Kinne (Editor), Oldendorf/Luhe, Germany
Penzlin (1989) Lehrbuch der Tierphysiologie. Gustav Fischer Verlag, Jena

Percy JA (1975) Ecological physiology of Arctic marine invertebrates. Temperature and salinity relationships of the Amphipod Onisimus affinis H. J. Hansen. J Exp Mar Biol Ecol 20:99-117

Poltermann M (1997) Biologische und ökologische Untersuchungen zur kryopelagischen Amphipodenfauna des arktischen Meereises. Ber Polarforsch 225:1-170

Poltermann M (1998) Abundance, biomass and small-scale distribution of cryopelagic amphipods in the Franz Josef Land area (Arctic). Polar Biol 20:134-138

Rakusa-Suszczewski S (1972) The biology of Paramoera walkeri Stebbing (Amphipoda) and the Antarctic sub-fast ice community. Pol Arch Hydrobiol 19(1):11-36

Ricker WE (1975) Computation and interpretation of biological statistics of fish populations. Bull Fish Res Board Can 191

Rumohr H, Brey T, Ankar S (1987) A compilation of biometric conversion factors for benthic invertebrates of the Baltic Sea. Baltic Mar Biol publ no. 9:1-47

Sagar PM (1980) Life cycle and growth of the Antarctic gammarid amphipod Paramoera walkeri (Stebbing, 1906). J R Soc N Z 10(3):259--270

Sainte-Marie B (1991) A review of the reproductive bionomics of aquatic gammaridean amphipods: variation of life history traits with latitude, depth, salinity and superfamily. In: Watling $\mathrm{L}$ (ed) VIIth International Colloquium on Amphipoda. Hydrobiologia 223:189-227

Steele DH, Steele VJ (1975) The biology of Gammarus (Crustacea, Amphipoda) in the north-western Atlantic, XI. Comparison and discussion. Can J Zool 53:1116-1126

Thurston MH (1970) Growth in Bovallia gigantea Pfeffer (Crustacea: Amphipoda). In: Holdgate MW (ed) Antarctic ecology, Vol. 1. Academic Press, London, p 269-278

Werner I (1997) Grazing of Arctic under-ice amphipods on sea-ice algae. Mar Ecol Prog Ser 160:93-99

Werner I, Auel H, Garrity C, Hagen W (1999) Pelagic occurrence of the sympagic amphipod Gammarus wilkitzkiu in ice-free waters of the Greenland Sea-dead end or part of the life-cycle? Polar Biol 22:56-60

Submitted: July 12, 1999; Accepted. September 13, 1999

Proofs received from author(s): January 31, 2000 